УДК 37.91.03: [008:32]

DOI https://doi.org/10.52726/as.pedagogy/2021.3.2.12

\author{
Л. В. КРУГЛЕНКО \\ кандидат педагогічних наук, \\ старший викладач кафедри іноземних мов, \\ Криворізький національний університет, \\ м. Кривий Ріг, Дніпропетровська область, Украӥна \\ Електронна пошта: kruhlenko@knu.edu.ua \\ https://orcid.org/0000-0002-0596-6926
}

\title{
ПЕРІОДИЗАЦІЯ РОЗВИТКУ ІДЕЙ ПОЛІКУЛЬТУРНОЇ ОСВІТИ У ВІТЧИЗНЯНІЙ ПЕДАГОГІЧНІЙ ДУМЦІ (к. ХХ - П. ХХІ ст.)
}

\begin{abstract}
Автором визначено, що серед пріоритетних напрямів розвитку вітчизняної системи освіти сучасна педагогічна наука визнає полікультурний вектор як такий, що забезпечує виконання двох завдань: входження України до європейського освітнього простору та розв'язання питань внутрішнього існування полікультурного суспільства. Означена проблема, як констатує автор, в історико-педагогічному дискурсі розглядається передусім у компаративному аспекті, натомість вітчизняний досвід «полікультурності» опинився на узбіччі наукового пошуку. Утім автор вважає, що таке дослідження дозволяє 3'ясувати динаміку розвитку ідей полікультурної освіти у вітчизняній педагогічній думці кінця XX - початку XXI ст., встановити головні тенденції цього процесу та визначити проблеми, які необхідно вирішувати саме сьогодні. Спираючись на думки вітчизняних вчених щодо важливості застосування методу періодизації в історико-педагогічному дослідженні, автором представлено власну періодизацію розвитку ідей полікультурності у вітчизняному педагогічному дискурсі. На основі визначених чинників (особливості політико-економічного та соціокультурного життя України у визначених хронологічних межах та актуалізація проблеми в освітніх регуляторних документах; наявність / відсутність наукових публікацій із визначеної теми в тогочасному педагогічному дискурсі; напрями, тенденції розвитку проблеми та практичний доробок вітчизняних вчених і педагогів-практиків тощо) розроблено таку періодизацію розвитку ідей полікультурної освіти у вітчизняній педагогічній думці: I-й період - теоретико-накопичувальний (кінець 80-х pp. XX ст. - перше десятиліття XXI ст.); II-й період - практикозорієнтований (друге десятиліття XXI ст. - триває нині); визначеним хронологічним періодам передував підготовчий етап (60-70-ті pp. XX ст.), на якому (в межах концепції інтернаціонального виховання) формувалися зародки ідей полікультурності. Утім у межах концепції пролетарського / соціалістичного інтернаціоналізму зародки ідей полікультурності (солідарність, рівність, братерство) були суттєво обмежені класовим принципом.

Доведено, що українські вчені мають створити таку модель полікультурної освіти, яка б відображала особливості державного розвитку України, іії багатонаціонального складу, проте відображала б загальні тенденції європейського співтовариства у їхньому прагненні до соціокультурного діалогу. Такий підхід буде продуктивним лише за умови врахування власного позитивного педагогічного минулого.
\end{abstract}

Ключові слова: полікультурність, полікультурна освіта, історико-педагогічне дослідження, періодизація, вітчизняна освіта.

Постановка проблеми. Серед пріоритетних напрямів розвитку вітчизняної системи освіти сучасна педагогічна наука визначає полікультурний вектор як такий, що забезпечує виконання двох завдань: входження України до європейського освітнього простору та розв'язання питань внутрішнього існування полікультурного суспільства. Визначальне місце полікультурності в освітньому просторі затверджено низкою міжнародних та вітчизняних нормативно-правових актів, серед яких: «Загальна декларація ЮНЕСКО про культурну різноманітність» (2001р.), «Конвенція ЮНЕСКО про охорону нематеріальної культурної спадщини» (2003р.), «Конвенція ЮНЕСКО про охорону та заохочення розмаїття форм культурного самовираження» (2005р.), Конституція України (1996р.), Декларація прав національностей України (1991р.); Закони України «Про громадянство», «Про освіту» (1991р.; 2016 р.), «Про національні меншини в Україні» (1992 р.), «Про повну загальну середню освіту» (2020 р.); укази президента України «Про національну доктрину розвитку освіти» (2002р.), «Про Національну стратегію розвитку освіти в Україні на період до 2021 року» (2012р.), розпорядження Кабінету Міністрів України «Про схвалення Концепції розвитку громадянської освіти в Україні» (2018р.) тощо. Значна кількість документів, на нашу думку, є переконли- 
вим свідченням важливості проблеми полікультурності для світової та вітчизняної освітньої спільноти.

Водночас маємо зазначити, що означена проблема в історико-педагогічному дискурсі розглядається передусім у компаративному аспекті. Натомість вітчизняний досвід «полікультурності», на жаль, опинився на узбіччі наукового пошуку. Утім таке дослідження дозволяє 3'ясувати динаміку розвитку ідей полікультурної освіти у вітчизняній педагогічній думці кінця XX - початку XXI ст., встановити головні тенденції цього процесу та визначити проблеми, які необхідно вирішувати саме сьогодні.

Аналіз попередніх досліджень. Зарубіжні надбання щодо особливостей розв'язання проблеми полікультурності у тій чи тій країні на нормативно-правовому, теоретико-науковому та практичному рівнях висвітлюють у своїх працях О. Байбакова, I. Бахов, Ю. Безух, I. Білецька, I. Гаганова, I. Гулецька, Т. Кристопчук, С. Лук'янчук, О. Мілютіна, О. Огієнко, О. Свиридюк, С. Сисоєва, Л. Сідун, Н. Шульга та інші. Проаналізований науковцями досвід доводить складність та неоднозначність сприйняття, розуміння та вирішення питання в освітньому просторі, дозволяє з'ясувати здобутки та прорахунки інших країн, обгрунтувати доцільність і визначити перспективні напрями впровадження ідей полікультурності у практику вітчизняної освіти.

Проблему полікультурної освіти у теоретичному та практичному ракурсах широко розглянуто у науковому доробку вітчизняних вчених. Зокрема, прикладні аспекти полікультурності в освіті, а саме формування полікультурної компетентності у студентів та учнів, вчителів та викладачів різних закладів освіти, фахівців різної кваліфікації (Л. Волик, Н. Ткачова, Чжань Ювень, Т. Чаркіна, А. Чирва, А. Щербакова, О. Цокур). У своїх дослідженнях науковці визначають методичний інструментарій щодо полікультурної освіти та 3'ясовують педагогічні умови формування полікультурної компетентності всіх учасників освітнього процесу.

Тому метою публікації $\epsilon$ визначення та обгрунтування конкретних етапів розвитку ідей полікультурної освіти у вітчизняній педагогічній думці, що дає можливість встановити особливості сьогодення та осмислити набутий досвід.
Виклад основного матеріалу. Варто зазначити, що практично всі історико-педагогічні дослідження, які висвітлюють розгортання певного педагогічного явища / процесу, мають часову визначеність, яка позначається як «хронологічні межі дослідження», що можуть мати більшу / меншу довготу, утім, дозволяють відстежити особливості становлення та буття, які переважно відображають суспільні запити на освіту. Утім, у своїй роботі ми спираємося на думку О. Сухомлинської [Сухомлинська], яку наводить Р. Чубук, про те, що «динаміка формування педагогічних ідей не завжди збігається 3 напрямом розвитку освіти. Вчена доповнює: «Як правило, вона випереджає освіту, але інколи не реагує на виклики часу. Бувають періоди, коли їхні шляхи взагалі розходяться, бо педагогічна думка - це втілення історії думки та духу, ідеалізована і романтизована рефлексія педагогічного процесу; це «педагогічний романтизм», за якого навчально-виховні ідеї втілюються, реалізуються 3 тією або іншою мірою вірогідності» [Чубук 2014 : 77].

Очевидно, що аналогічний процес відбувся з ідеєю полікультурності і в іiі освітньому розумінні. Вивчення джерельної бази дослідження зумовило логіку наукового пошуку відповідно до системи чинників, які, на нашу думку, впливали на розуміння сутності ідеї полікультурності як концептуальної основи здійснення полікультурної освіти (зміст та особливості організації). До таких чинників було віднесено:

- особливості політико-економічного та соціокультурного життя України у визначених хронологічних межах та актуалізацію проблеми в освітніх регуляторних документах;

- наявність / відсутність наукових публікацій із визначеної теми в тогочасному педагогічному дискурсі;

- тенденції розвитку проблеми та практичний доробок вітчизняних учених і педагогівпрактиків тощо.

Сьогодні артикуляція проблеми в освітньому науково-практичному дискурсі була підготовлена низкою об'єктивних передумов політико-економічного та соціокультурного розвитку країн світу (зокрема України), серед яких: утворення світових міждержавних об'єднань (наприклад, ЄС), нівелювання культурних та інформаційних кордонів, інтенсив- 
ний розвиток міжкультурної комунікації, формування та поширення концепту «всі різні, але всі рівні» на всі сфери людського буття (зокрема й на освіту), прагнення України до вступу до європейського освітнього співтовариства тощо. Утім, окремі ії прояви дослідники простежують ще задовго до появи власне поняття «полікультурності». Частково іії торкаються практично всі науковці, коли визначають коло педагогів, освітян, культурних діячів, які стоять у витоків ідей полікультурності та/чи зробили значний внесок у формування та розвиток цих прогресивних педагогічних ідей у конкретних соціокультурних умовах. Так, до педагогічних концепцій, у яких було закладено ідеї, що були значно розвинені у концепціях полікультурної освіти, науковці (С. Авхутська, К. Дворнікова, С. Сисоєва, Т. Сніца, Л. Чумак, О. Яровв та ін.) відносять: Я. А. Коменського (програма універсального виховання людства «Панпедія»), П. Каптєрєва (ідеї взаємозв'язку в педагогіці національного та загальнолюдського), С. Гессена (єдність процесів виховання: загальнолюдського та національного) та ін. О. Ярова, зокрема, зазначає, що Я. Коменський «у трактаті «Лабіринт світу та рай серця» (Labyrint světa a ráj srdce 1623) розглядав проблеми корисності знання, самореалізації людини в житті, залучення людства до загальної мудрості (пансофії), навчання впродовж життя, мирного співіснування в багатонаціональному світі», що дослідниця вважає ознакою «зародження полікультурної освіти» [Ярова 2018: 130]). Л. Чумак виявляс елементи поняття «полікультурного виховання» в педагогічній спадщині К. Ушинського, А. Макаренка, В. Сухомлинського [Чумак, 2011]. Звернення до проблеми полікультурності «видатними діячами освіти і культури України, з-поміж яких Г. Ващенко, В. Вернадський, В. Винниченко, М. Грушевський, М. Драгоманов, О. Духнович, В. Короленко, М. Пирогов, С. Русова, Д. Чижевський та інші», констатує І. Бахов [Бахов 2017 : 435].

Безумовно, історія розвитку світової та вітчизняної педагогічної думки містить чимало міркувань видатних педагогів щодо особливостей національного / етнічного виховання молодої людини в різних соціокультурних умовах. Освітні концепції минулого, за справедливим твердженням I. Бахова, «розкриваються в нерозривному зв'язку з проблемами націо- нального визволення українства, боротьбою народу з відкритими чи прихованими формами культурної, соціальної та іншої дискримінації» [Бахов 2017 : 435]. Тому свої «пошуки» витоків ідей полікультурності проводимо з радянських часів, а саме 3 концепції інтернаціонального виховання.

Також додамо, що сьогодні ця «ідея» переживає певне відродження. У 70 - 80-ті рр. $\mathrm{XX}$ ст. вона була безпосередньо пов' язана з класовим підходом та визнавала повагу та дружні стосунки між тими (братніми) республіками чи країнами, що будували соціалізм, та пропагувала непримиренність до країн «буржуазного табору». Власне, в такому вигляді, на нашу думку, вона й повинна залишитися в педагогічному дискурсі, оскільки час та розвиток світової педагогічної думки XX ст. запропонував інший - полікультурний концепт. Проте сьогодні вітчизняна педагогічна думка демонструє певну інертність у визначеному напрямі. Так, у публікації А. Касперського та I. Бондаренко (2015 р.) читаємо: «Інтернаціональне виховання - це залучення молодих людей до економічних, політичних, соціальних, культурологічних та інших цінностей, створених народами світу, формування поваги до міжнародного суспільного досвіду, бажань і вмінь його переймати, допомагати представникам інших етносів, суспільств та держав у вирішенні питань і проблем. Однією з базових основ цього напряму виховання $є$ кількісне і якісне зростання обсягу знань студентів про інші етноси (народи), держави, суспільства, їх досягнення у різних сферах людської життєдіяльності. Важливо під час навчального процесу постійно підкреслювати інтернаціональний характер науки, звертати увагу на співпрацю народів і держав у вирішенні проблем глобального характеру.

Інтернаціональне виховання органічно доповнює патріотичне виховання, допомагає глибше усвідомити місце і роль України у світі, чітко визначити шляхи іiі інтеграції у європейське і світове співтовариства» [Касперський 2015 : 198]. Наведене судження, на нашу думку, свідчить про осучаснення поняття «інтернаціональне виховання». Ті функції, які автори приписують «інтернаціональному вихованню», має виконувати полікультурне виховання. Тож 
«відновлення» інтернаціоналізму в сучасних умовах вважаємо недоречним.

Пострадянський період розвитку вітчизняної освіти позначений пошуком власних концептів, які передусім відшукували у зарубіжних теоріях полікультурної освіти, що загалом дає підстави для узагальнення стосовно причин їхнього виникнення, до яких (услід за іншими науковцями) відносимо необхідність подолання кризових суспільних явищ (расизм, дискримінація, етнічне насильство тощо). Ці явища не мали чіткого оформлення на пострадянському просторі, де десятиліттями пропагувалися ідеї пролетарського інтернаціоналізму.

Власне, ідея полікультурності в освіті мала інше спрямування, передусім вона мала сприяти інтернаціоналізації освіти, включенню України у світовий освітній простір. Більш широко (відповідно до світових стандартів) полікультурна освіта почала трактуватися як запобіжник будьяких проявів дискримінації в освіті та соціальних розшарувань на етнічній (національній) основі лише на початку XXI століття. Саме на цей час припадає розуміння засадничого значення ідеї полікультурності для освіти -ідеї соціокультурної рівності всіх суб' єктів

Загалом у вітчизняному освітньому просторі сьогодні накопичується значна кількість робіт, що стосуються зарубіжного досвіду стосовно полікультурної освіти та дозволяють провести певну паралель із вітчизняним досвідом у визначеному напрямі, встановити можливість відтворення / створення власної моделі полікультурності, полікультурної освіти. При цьому особливу увагу звертаємо на дослідження П. Кендзьора, який стверджує, що «концепція полікультурного виховання грунтується на провідних теоріях світової культури: концепціях діалогу, конвергентності, інтеграції та 3 особливим наголосом на процесах суспільної консолідації. Отже, аналіз стійких елементів дає можливість говорити про культуру загалом, а дослідження відмінностей - про унікальність кожної зокрема. А це, відповідно, уможливлює інтеграцію нових знань про ту чи іншу культуру до вже наявних і веде до моделювання поведінки індивіда» [Кендзьор 2016 : 41].

Отже, на основі визначених критеріїв та чинників (сталі та змінні) (особливості політико-економічного та соціокультурного життя
України у визначених хронологічних межах та актуалізація проблеми в освітніх регуляторних документах; наявність / відсутність наукових публікацій із визначеної теми в тогочасному педагогічному дискурсі; напрями, тенденції розвитку проблеми та практичний доробок вітчизняних вчених і педагогівпрактиків тощо) нами було розроблено таку періодизацію розвитку ідей полікультурної освіти у вітчизняній педагогічній думці: I-й період - теоретико-накопичувальний (кінець 80-х pp. XX ст. - перше десятиліття XXI ст.); II-й період - практико-зорієнтований (друге десятиліття XXI ст. - триває нині). Вважаємо, що визначеним хронологічним періодам передував підготовчий етап (60-70-ті pp. ХХ ст.), на якому (в межах концепції інтернаціонального виховання) формувалися зародки ідей полікультурності. Утім, у межах концепції пролетарського / соціалістичного інтернаціоналізму зародки ідей полікультурності (солідарність, рівність, братерство) були суттєво обмежені класовим принципом.

1 період - теоретико-накопичувальний (кінець 80-х рp. XX ст. - перше десятиліття XXI ст.) - характеризувався реформаторськими діями в освітній царині в радянську добу «перебудови» та в перше десятиліття державної незалежності України. До негативних тенденцій цього періоду відносимо: посилення ідеологічної боротьби між країнами соціалістичного табору та «імперіалістичними державами», що позначилося на пропагуванні ідей соціалістичного інтернаціоналізму, дружби та братерства виключно між країнами PEB та «непримиренності до буржуазної ідеології і моралі». Серед позитивних тенденцій відзначаємо: інтерес вітчизняної педагогічної науки до питань виховання учнівства в умовах культурної різноманітності; вивчення та поширення досвіду 3 інтернаціонального виховання; затвердження загальних положень світової спільноти щодо ідей полікультурності у вітчизняних нормативних документах, що відкрило широкі можливості для проведення теоретичних досліджень у визначеному напрямі.

2 період - практико-зорієнтований (друге десятиліття XXI ст. - триває нині). Саме у цей час відбувається зміна в домінантних концептуальних положеннях нормативних документів 
(Національна стратегія розвитку освіти в Україні на період до 2021 року, 2012 р.; Закони України «Про освіту», 2017 р. та «Про повну загальну середню освіту», 2020 р.), якими зміцнювалася ідея інтегрування вітчизняної системи освіти до світового освітнього простору, зокрема, шляхом інституціоналізації провідних ідей світового співтовариства (толерантність, культурний діалог, визнання рівності, самобутності та неповторності культурних надбань усіх людей та соціальних груп). На початок другого десятиріччя XXI ст. вивчення ідеї полікультурності перейшло в нову фазу, яка, на наш погляд, характеризується ствердженням в освітньому просторі думки про те, що полікультурність (полікультурна компетентність) є запорукою запобігання негативним проявам глобалізації. Можемо стверджувати, що сьогодні проблема полікультурності переважно розглядається у прикладному (як розробка педагогічних механізмів упровадження) аспекті. До суперечливих тендениій цього періоду відносимо: недостатню увагу вітчизняних учених до теоретичного ракурсу проблеми на користь іï практичного аспекту; зосередженість науковців переважно на вивченні механізмів здійснення полікультурного виховання, що обмежує саму проблему виховною сферою. Серед позитивних тендениій: ствердження в освітньому дискурсі ідей про виховання молоді на засадах національних та європейський цінностей, толерантного ставлення до «культури, мистецтва, вірувань інших народів», важливості створення недискримінаційного освітнього середовища тощо. Серед провідних тенденцій розвитку освіти сьогодні $\epsilon$ прагнення до подолання освітніми засобами будь-яких проявів дискримінації різних верств населення, що, на нашу думку, також є одним із ключових компонентів полікультурності.

Висновки. Як узагальнення маємо зауважити, що світові надбання у сфері полікультурності переконують у тому, що кожна країна намагається вирішити проблему відповідно до особливостей власного розвитку та наявності певних, зокрема освітніх, ресурсів. Наявні сьогодні «моделі полікультурності» мають свою національну специфіку, тож «запропоновані» світовою спільнотою національні варіанти розв'язання проблеми не можуть бути повністю експлікованими на вітчизняний грунт. Переконані, що українські вчені мають створити свою модель як полікультурності, так і полікультурної освіти, яка б відображала не лише особливості державного розвитку України, іiі багатонаціонального складу, а й загальні тенденції європейського співтовариства у їхньому прагненні до соціокультурного діалогу. Такий підхід буде продуктивним лише за умови урахування власного позитивного педагогічного минулого.

\section{ЛІТЕРАТУРА}

1. Бахов І. С. Тенденції розвитку полікультурної освіти у професійній підготовці фахівців Канади і США (друга половина XX - початок XXI ст.) : дис. ... д-ра педагог. наук : 13.00.04. Київ, 2017. 624 с.

2. Касперський А. В., Бондаренко I. М. Національно-патріотичне виховання майбутніх учителів технологій. Збірник наукових праць Кам'янеиь-Подільського нащіонального університету ім. Івана Огієнка. Серія : Педагогічна. 2015. Вип. 21. С. 197-200.

3. Кендзьор П. І. Полікультурне виховання учнів у системі діяльності загальноосвітнього навчального закладу : дис. .... д-ра педагог. наук : 13.00.07. Київ, 2017. 504 с.

4. Сухомлинська О. В. Періодизація педагогічної думки в Україні: кроки до нового виміру. Iсторико-педагогічний прочес: нові підходи до загальних проблем. Київ : 2003. С. 47-66.

5. Чубук Р. В. Наукові ідеї превентивного виховання в історії педагогічної думки (XI-XVIII ст.). Наукові прачі [Чорноморського державного університету імені Петра Могили комплексу «Києво-Могилянська академія»]. Серія : Педагогіка. 2014. Випуск 234. Том 246. С. 77-82.

6. Чумак Л. В. Полікультурне виховання учнів середніх (5-8) класів в умовах родинно-шкільного освітнього простору : автореф. дис. ... канд. педагог. наук : 13.00.07. Тернопіль, 2011. 22 с.

7. Ярова О. Б. Тенденції розвитку початкової освіти в країнах Європейського Союзу : дис. ... д-ра педагог. наук : 13.00.01. Київ, 2018. $531 \mathrm{c.}$

\section{REFERENCES}

1. Bakhov, I. (2017) Tendentsii rozvytku polikulturnoi osvity u profesiinii pidhotovtsi fakhivtsiv Kanady i SSA (druha polovyna XX - pochatok XXI st.) [Trends in the development of polycultural education in the training of specialists in Canada and the United States (the second half of the XX - early XXI century.)]: dys. ... d-ra pedahoh. nauk : 13.00.04. Kyiv, 2017. 624 s. [in Ukrainian].

2. Iarova, O. (2018) Tendentsii rozvytku pochatkovoi osvity v krainakh Yevropeiskoho Soiuzu [Trends in the development of primary education in the European Union]: dys. ... d-ra pedahoh. nauk : 13.00.01. Kyiv, 2018. 531 s. [in Ukrainian]. 
3. Kasperskyi, A., Bondarenko, I. (2015) Natsionalno-patriotychne vykhovannia maibutnikh uchyteliv tekhnolohii [National and patriotic education of future teachers of technology]. Zbirnyk naukovykh prats Kamianets-Podilskoho natsionalnoho universytetu im. Ivana Ohiienka. Seriia : Pedahohichna. 2015. Vyp. 21. S. 197-200. [in Ukrainian].

4. Kendzor, P. (2017) Polikulturne vykhovannia uchniv u systemi diialnosti zahalnoosvitnoho navchalnoho zakladu [Polycultural education of students in the system of activity of a general educational institution]: dys. ... d-ra pedahoh. nauk : 13.00.07. Kyiv, 2017. 504 s. [in Ukrainian].

5. Sukhomlynska, O. (2003) Periodyzatsiia pedahohichnoi dumky v Ukraini: kroky do novoho vymiru [Periodization of pedagogical thought in Ukraine: steps to a new dimension]. Istoryko-pedahohichnyi protses: novi pidkhody do zahalnykh problem. Kyiv : 2003. S. 47-66. [in Ukrainian].

6. Chubuk, R. (2014) Naukovi idei preventyvnoho vykhovannia v istorii pedahohichnoi dumky (XI-XVIII st.) [Scientific ideas of preventive education in the history of pedagogical thought (XI-XVIII centuries)]. Naukovi pratsi [Chornomorskoho derzhavnoho universytetu imeni Petra Mohyly kompleksu "Kyievo-Mohylianska akademiia"]. Seriia : Pedahohika. 2014. Vypusk 234. Tom 246. S. 77-82. [in Ukrainian].

7. Chumak, L. (2011) Polikulturne vykhovannia uchniv serednikh (5-8) klasiv v umovakh rodynno-shkilnoho osvitnoho prostoru [Multicultural education of middle (5-8) grade students in a family-school educational space]: avtoref. dys. ... kand. pedahoh. nauk : 13.00.07. Ternopil, 2011. 22 s. [in Ukrainian].

\section{V. KRUHLENKO}

Candidate of Pedagogical Sciences,

Senior Lecturer at the Department of Foreign Languages,

Kryvyi Rih National University,

Kryvyi Rih, Dnipropetrovsk region, Ukraine

E-mail:kruhlenko@knu.edu.ua

https://orcid.org/0000-0002-0596-6926

\section{PERIODIZATION OF THE DEVELOPMENT OF IDEAS OF POLYCULTURAL EDUCATION IN NATIONAL PEDAGOGICAL THOUGHT (late XX - early XXI centuries)}

The author determined that among the priority areas of development of the national education system, modern pedagogical science recognizes the polycultural vector as one that ensures the fulfilment of two tasks: Ukraine's entry into the European educational space and solving the internal existence of a polycultural society. This problem, the author states, in the historical and pedagogical discourse is considered primarily in a comparative aspect, but the domestic experience of "polyculturalism" has found itself on the sidelines of scientific research. However, such a study, the author believes, makes it possible to find out the dynamics of the development of the ideas of polycultural education in the national pedagogical thought of the late XX - early XXI centuries, to establish the main trends of this process and to determine the problems that need to be solved today. Based on the opinions of national scientists about the importance of applying the method of periodization in historical and pedagogical research, the author presents her own periodization of the development of ideas in the field of culture in national pedagogical discourse. Based on certain factors (features of the political, economic and socio-cultural life of Ukraine in a certain chronological framework and the actualization of the problem in educational regulatory documents, the presence/absence of scientific publications on a specific topic in the pedagogical discourse; directions, trends in the development of the problem and the practical groundwork of Ukrainian scientists and teachers practitioners, etc.), such a periodization of the development of the ideas of polycultural education in national pedagogical thought has been developed: $1^{\text {st }}$ period - theoretical-cumulative (late 80 s of the XX century the first decade of the XXI century) II $^{\text {nd }}$ period - practice-oriented (the second decade of the XXI century - continues till the present time) certain chronological periods were preceded by a preparatory stage (60-70s of the XX century), at which (within the framework of the concept of international education) the embryos of the ideas of polyculturalism were formed. However, within the framework of the concept of proletarian / socialist internationalism, the embryos of the ideas of polyculturalism (solidarity, equality, brotherhood) were significantly limited by the class principle.

It is proved that Ukrainian scientists should create such a model of polycultural education that would reflect the peculiarities of the state development of Ukraine, its multinational composition, but would reflect the general tendencies of the European community in their desire for sociocultural dialogue. This approach will be productive only if you take into account your own positive pedagogical past.

Key words: polyculturalism, polycultural education, historical and pedagogical research, periodization, national education. 